\title{
Prof. Arun Kumar Sharma (1924-2017)
}

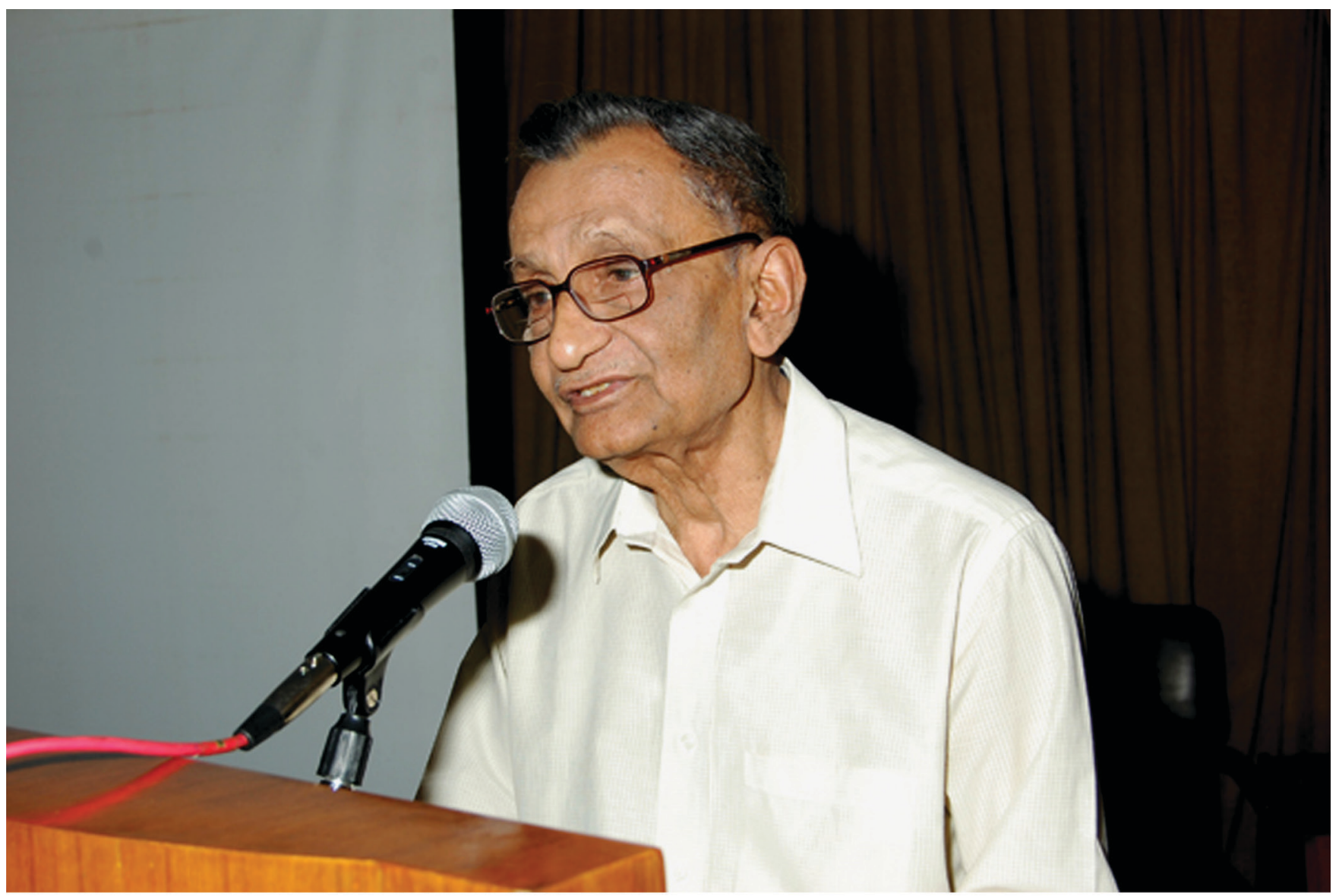

Prof. A. K. Sharma (31.12.1924-06.07.2017)

Padma Bhushan Professor Arun Kumar Sharma, one of the doyens of botany in general and cytogenetics and cytotaxonomy in particular, died on $6^{\text {th }}$ July 2017, Thursday at an age of 92 . He made a benchmark both at national and international level. His fame reached the zenith of success through his hard work but his success kept him humble as a human. Besides his own research activities on various domains of botany, he has significantly contributed to the policy, planning and formulation of scientific and technical programmes for the growth of science in India.

Prof. Sharma was born on $31^{\text {st }}$ December, 1924 and lost his father Charu Chandra Sharma at a very young age.
His mother Shovamoyee Sharma stood like a strong pillar through the thick and thin of his life. After completing his basic schooling from Mitra Institution (1933-1939) he obtained his B.Sc degree from Asutosh College (1941-43) and M.Sc from University of Calcutta (1943-45). He got his initial training in chromosome from Prof. P.N. Bhaduri. He started his career as an Assistant Professor (1948) at Department of Botany, University of Calcutta and also gradually became the Professor and also as the Head of the department. For his outstanding research contributions he was honored with D. Sc. degree in 1955. In the year 1969 Prof. Sharma became the 'Sir Rashbehari Ghose 
Chair Professor' in the Department of Botany, University of Calcutta. Prof. Sharma was an extraordinary teacher, scientist and held exorbitant knowledge in all branches of botany. Prof A.K. Sharma has guided 60 students for Ph. D. and 10 of his eminent students have been honored with the D. Sc. degree.

Prof. Sharma made significant contributions in Science and Technology and was involved in various scientific related work post independence era. Prof. A.K. Sharma initiated and with constant rigor made an excellent mark in the chromosome study. In the study of plant genetics he made significant contributions in the research on chromosomes. He established the chromosome research centre in the Calcutta University where several new areas of chromosome research were initiated.

Prof. A. K. Sharma was a member of the team constituted for the reorganization of the Botanical Survey of India (BSI) by Govt. of India in the year 1948 under the leadership of Dr. K. P. Biswas along with other members namely R. S. Rao, Dilwar Hossasin, D. D. Awasthi and Sunil K. Mukherjee (all were research fellows of BSI and A. K. Sharma was a registered fellow of Botany Department, C.U.). Later Dr. E. K. Janaki Ammal took the charge and succeeded Dr. Biswas in the year 1952.

Prof Sharma along with his students were engaged in developing innovative methods for chromosome study, noteworthy amongst them are aesculine, isopsoralene and umbelliferone for chromosome analysis as well as Orcein banding technique for repeated DNA sequences. Water as a pre treatment agent and the cause of breakage or clarification of chromosome were also resolved.

Prof. Sharma and his team made significant contributions to the field of systematic and evolutionary trends in different Monocotyledons and Dicotyledons taxa on the basis of cytological data. A digital account of plant chromosome work done by Prof. AKS and his group since 1950 on more than 1500 species was released by the Department of Biotechnology during the 100th session of the Indian Science Congress on 5 January 2013 at Kolkata. Prof. Sharma has great contribution on the cytotaxonomy study of Himalayan plants under the "US PL 480 project". All materials related to this study have been incorporated in CUH recently.

In asexually reproducing species like lilies, amaryllids, aroids and other families of monocotyledons, it was revealed that such species show dynamic differential chromosome behaviour. Such species continually produce new genotypes and cultivars despite the absence of the regular method of reproduction and fertilization, indicating that they have developed alternative methods of generating variability.

These findings drive Prof Sharma to establish 'A new concept of speciation. The concept defines that in asexually reproducing species, the somatic tissue represents a chromosome mosaic in which the normal complement occurs in highest frequency.

He had immense contribution in the fields like induction of cell rejuvenescence and control of differentiation, repeated DNA sequences and dynamic DNA, concept of chromosome dynamism, chromosome chemistry. Prof. Sharma contributed a lot as pioneer in the chromosome painting research.

AKS also worked on problems related to environment, originally emanating from his studies on genetic effects of physical and chemical agents. His Presidential Address at the $68^{\text {th }}$ Session of the Indian Science Congress on "The impact of development of science and technology on environment" provided incentives for the introduction of a number of programmes for conservation of environment and abatement of pollution in India - so much so, the creation of the Department of Environment of Government of India owes much to the recommendations based on this focal theme. At this stage Indira Gandhi, the then Prime Minister of India wanted him to become the first Secretary of the newly created Department of Environment. However, he could not undertake the same because of his commitment to the Department of Botany, University of Calcutta.

He authored over 600 research papers including 6 in Nature, several papers in Chromosoma, Naturwissenschaften, and hosted top notch specialized journals and contributed invited reviews/articles to Botanical Review, Chromosome Today, The Cell Nucleus, International Review of Cytology, Encyclopedia of Microtechnique, Biology International, etc.

In 1958 only at an age of 34 Prof. Sharma started to publish the international journal named "Nucleus". Prof. Sharma along with his wife Prof. Archana Sharma together published the classic book named' Chromosome Techniques: Theory and Practises' published by Buttorworth, London in the year 1965. Till date this is a remarkable book and is followed widely by most of the laboratories. The Nucleus is running in the $60^{\text {th }}$ year of its publication 
and is published by Springer. He also served on the Editorial boards of many journals including Cytologia, Proceedings of the Indian National Science Academy, Journal of Cytology and Genetics, Preceedings of the Indian Academy of Sciences and Indian Journal of Experimental Biology, etc.

Due to his significant research work and incredible impact in Science he was honored with the Greatest award of all time, the 'Padmabhusan'. For his outstanding contributions in the field of chromosome research he was honoured as the Jawaharlal Nehru fellow, National Lecturer UGC (1972-76) and later on as the golden Jubilee Professor of the Indian Science Academy from 1985-1990 at the University of Calcutta. Apart from this he was also awarded S.S Bhatnagar (1976), Paul Bruhl Memorial Medal (1974), Asiatic society, Birbal Sahni Medal -Indian Botanical Society (1974), First JC Bose award -UGC (1976), Silver Jubilee Medal - INSA (1976), VASVIK Award (2003), Eminent Teacher of Distinction-University of Calcutta (2006), Rathindra Puraskar-Visva Bharati (2008), Life Time Achievement Award-Indian Botanical Society (2010).

He was chairman of National Science Academy, New Delhi (1983-84), National Academy Of Sciences, India (2010-2012) and Federation of Asian Scientific Academics and Societies (1984-1989). Prof. A. K. Sharma also served as a chairman of the Bioresearch committee of CSIR and ICMR. He was also a member of the Life Science Panel of UGC and DST's Science and Research procedure. He was also the chairman, co-chairman and trustee of various research institutes. Indian National Committee of IUBS-INSA (1978), Man and Biosphere Committee, Department of Environment (1981-89), FASAS Commission On Science And Technology For Development in Asia (1990), Chairman Biological Sciences, Fellowship Committee of the World Academy of Sciences (TWAS), Trieste (1991-1998), Co-chairman, Global Continuing Committee On Role of Scientific and Engineering Societies in Development (AAASINSA-ISCA) (1980), Birla Industrial and Technological Museum, Kolkata (1990-98), Plant Biotechnology Committee, DBT (1997-till Death), Chairman, Steering Committee, National Bioresource Development Board, Government of India (2000-till date), Plant Sciences Research Committee, CSIR (1998-2004); Member, Executive Committee, IUBS, Paris (1982-85), IUBS Steering Committee on Biological Monitoring of the State of Environment (1983), trustee International Foundation of Science, Stockholm (1984-87). He has also served as the chairman of the research council of Birbal Sahan Institute of Palaeobotany, Lucknow. National Botanical Research Institute, Lucknow and National Institute of Plant Genome Research, New Delhi.

Prof. Sharma's contribution to Science and Technology was recognized worldwide. He was invited to act as the chairman and panel specialist of various sessions and International Scientific Meetings namely chairman of the section on Chemical Mutagens at the International Congress of Genetics at Montreal (1958), Tokyo (1968), Leader of the Indian delegation to the International Congress of Genetics at the Hague (1963), International Congress of Cell Biology at Berlin (1980), Chairman of the section Newer Concepts of Structural Organization of Chromosomes, New Delhi (1983). He attended the International Congress of Cyto and Histochemistry at Frankfurt (1964) as Panel Expert. Invited speaker at the Oxford Chromosome Conference $(1967,1970,1977)$, International Botanical Conference at Seattle (1969), Tropical Botanical Conference at Denmark (1978), visited Norway as official delegate to the IUBS General Assembly (1973), UNCSTD conference at Vienna (1978). Prof. Sharma had been to Washington (1980) as the chairman of the Joint Organization Committee of the Global Seminar on the Role of Scientific Societies in Development, jointly organized by the American Association of Advancement of Science, Indian Science Congress Association and Indian National Science Academy, the final conference being held in Delhi on December 1-5, 1980, in which about 50 countries were represented. As President of Indian National Science academy and later as Founding President, FASAS. Prof. Sharma visited a number of Academies in different countries of Asia, Europe and USA, on invitation of giving lectures (1995-1999).

He was a great teacher, eminent scientist and a pioneer in the modern chromosome research. His contributions were internationally acclaimed and appreciated. It was a mere fortune for all those who got to know a personality like him. He ignited the light of scientific temper and was humble to the core.

$$
\begin{array}{r}
\text { D. Maity } \\
\text { Botany Department, Calcutta University } \\
\text { P. Singh } \\
\text { Botanical Survey of India }
\end{array}
$$




\section{PUBLICATIONS:}

A.K. Sharma and A. Sharma. Chromosome Techniques - Theory and Practice, Butterworths, London, Three editions 1965, 1972, 1980.

A.K. Sharma and A. Sharma (eds). Nucleus, Proc. International Seminar on Chromosome, its structure and function. Suppl. Volume, 1968.

A.K. Sharma and A. Sharma (eds). Chromosome in Evolution of Eukaryotic Groups, CRC Press, USA, 1983, 1984, vols 1 and 2.

A.K. Sharma and A. Sharma (eds). Impact of the Development of Science and Technology on Environment, Indian Science Congress Association, 1981.

A.K. Sharma and A. Sharma. Chromosome Techniques - A Manual, Harwood Academic Publishers, Amsterdam, 1994.

A.K. Sharma and A. Sharma. Plant Chromosomes - Analysis, Manipulation and Engineering, Harwood Academic Publishers, Amsterdam, 1999.

A.K. Sharma and A. Sharma (eds). 07 Volume Series on Plant Genome, Biodiversity and Evolution, Science Publishers, USA: Volume 1, Part A, Phanerogams - Lower Groups, 2003; Volume 1, Part B, Phanerogams - Higher Groups, 2005; Volume 1, Part C, Phanerogams - Angiosperm: Dicotyledons, 2006; Volume 1, Part D,Phanerogams - Gymnosperm and Angiosperm: Monocotyledons, 2006; Volume 1, Part E, Phanerogams -Angiosperm, 2008; Volume 2, Part A, Lower Groups, 2004; Volume 2, Part B, Lower Groups, 2006.

A.K. Sharma and A. Sharma (Guest editors). Methods in Cell Science, Special issue: Synchronization in Mammalian Systems, Kluwer, Boston, 1996, vol. 18.

A.K. Sharma and A. Sharma (Guest editors). Methods in Cell Science, Special issue: Synchronozation in Plant Cells, Kluwer, Boston, 1999, vol. 21.

A.K. Sharma and A. Sharma (Guest editors). Methods in Cell Science: Special issue: Chromosomes Painting - Principles, Strategies and Scope, Kluwer, Boston, 2001, vol. 23 (nos 1-3).

A.K. Sharma (ed.). History of Science in India. Intro.vol. + vols.I(Part I\&II), II, III, IV (Part I\&II), V, VI, VII\&VIII. Ramakrishna Mission Institute of Culture, Golpark, Kolkata, India, 2014-15.

A.K. Sharma (1947). A cytological investigation of incompatibility between Cosmos bipinnatus Cav. And C. sulphureus Cav. Bull. Bot. Soc. Beng. 1 : 19-26.

P.N. Bhaduri and A.K. Sharma (1947). Cytogenetics of Datura fastuosa L. Bull. Torrey Bot. Club 73 : 438-450.

A.K. Sharma (1949). Indian Sphagnums. Bull. Bot. Soc. Bengal $3: 99-111$.

A.K. Sharma and C. Ghosh (1950). Oxyquinoline-as an ingredient in a new fixative for chromosome analysis. Sci. Cult. 16 :268-289.

A.K. Sharma (1950). Chromosome chemistry and the recent techniques for its study. Sci. Cult. 16 : 134-142.
A.K. Sharma and C. Ghosh (1951). Oxyquinoline-its possibilities in other cytological procedures. Sci. Cult. 16 : 528-529.

A.K. Sharma (1951). Trichloracetic acid and Feulgen staining. Nature 167 : 441-442.

D. Bhattacharjee and A.K. Sharma (1951). Phosphatase in mitotic and meiotic cycleof plant chromosomes. Sci. Cult. 17 : 268-269.

A.K. Sharma and D. Bhattacharjee (1952). Permanent mounts of chromosomes after B-oxyquinoline and squashing. Stain Techn. $27: 201-203$.

A.K. Sharma (1952). Desoxyribonucleic acid - the problem of its function location and reactions. Port. Acta Biol. 3 : 289-317.

A.K. Sharma and D. Bhattacharjee (1952). Effect of trichloracetic acid on nuclear proteins. Nature $169: 417$.

A.K. Sharma and A.K. Bal (1953). Coumarin in chromosome analysis. Stain Techn. 28 : 255-257.

A.K. Sharma and D. Bhattacharjee (1953). Somatic reduction in untreated Leguminous plants. Genetica 26 : 410-414.

A.K. Sharma A. Mookerjea and C. Ghosh (1953). Alkaline phosphatase technique in plant chromosomes. Port. Acta Biol. 3 : 341-354.

A.K. Sharma and A. Mookerjea (1954). Possibilities of the use of hormones in chromosome analysis. Caryologia 6 : 52-62.

A.K. Sharma and D.N. De (1954). Gallic Acid - its importance in cytochemical studies. Caryologia 6 : 180-189.

A.K. Sharma and N.K. Bhattacharyya (1954). Treatment of roottips in phenols for the study of karyotype.Curr. Sci. 23 :232-233.

A.K. Sharma and S. Sen (1954). Study of the effect of water on nuclear constituents. Genet. Iber. 6 : 19-32.

A.K. Sharma and N.K. Das (1954). Study of karyotypes and their alternations in Aroids. Agron. Lusit. 16 : 23-48.

A.K. Sharma and C. Ghosh (1954). Further investigation on the cytology of the family Amaryllidaceae and its bearing on the interpretation of its phylogeny. Genet. Iber. 6 : 71-100.

A.K. Sharma and C. Ghosh (1954). Cytogenetics of some of the Indian Umbellifers. Genetica 27 : 17-44.

A.K. Sharma and A. Mookerjea (1954). Induction of division in cells-a study of the causal factors involved. Bull. Bot. Soc. Bengal G.C. Bose Mem. vol. 8 : 24-100.

A.K. Sharma and S. Sen (1954). Induction of division through nucleic acid treatment. Caryologia 6 : 151-159.

A.K. Sharma and A. Mookerjea (1955). Paradichlorobenzene and other chemicals in chromosome work. Stain Techn. 30 : 1-7.

A.K. Sharma and M. Roy (1955). Orcein staining and the study of the effect of chemicals on chromosomes. Chromosoma 7 : 275-280.

A.K. Sharma and S.K. Sarkar (1955). A new technique for the study of chromosomes of palms. Nature 176 : 261. 
A.K. Sharma and A. Majumdar (1955). Cytological peculiarity of Pteris longifolia and its importance in evolution. Sci. Cult. 21 : 338-339.

A.K. Sharma (1955). Cytology of some of the members of Commelinaceae and its bearing on the interpretation of phylogeny. Genetica 27 : 323-363.

A.K. Sharma and R.N. Mukherji (1955). Cytology of two members of Alismaceae. Bull. Bot. Soc. Bengal 9 : 32-35.

A.K. Sharma and N.K. Bhattacharyya (1955). Cytogenetics of some members of Menispermaceae. Bull. Bot. Soc. Bengal 9 : 159-169.

A.K. Sharma and R. N. Mukherji (1955). Induction of chromosomal abnormalities through chemicals in pollen mother cells of Allium cepa. Genet. Iber. 7 : 57-64.

A.K. Sharma (1956). Fixation of plant chromosomes its principles limitations and recent developments. Botanical Review 22 : 665-695.

A.K. Sharma and S.K. Sarkar (1956). Veratrine its use in cytochemistry. Caryologia 8 : 240-249 1956.

A.K. Sharma and D.N. De (1956). Heterocyclic bases - an aspect of their use in cytochemistry. Øyton $6: 23-46$.

A.K. Sharma and N.K. Bhattacharyya (1956). An investigation on the possibilities of the use of phenols in chromosome analysis. Genetica 28 : 121-142.

A.K. Sharma and A.K. Bal (1956). An investigation on the effect of certain chemicals on the nucleus and their possibilities in chromosome analysis in plants. Proc. Nat. Inst. Sci. India 22 : 57-68.

A.K. Sharma and N.K. Bhattacharyya (1956). Chromosome breakage through paradichlorobenzene treatment. Cytologia 21 : 353-360.

A.K. Sharma (1956). Improvements in chromosome fixation. Sci. Cult. 21 : 648-650.

A.K. Sharma (1956). A new concept of a means of speciation in plants. Caryologia 9 : 93-103.

A.K. Sharma and A. Sharma (Née Mookerjea) (1956). Fixity in chromosome number of plants. Nature 177 : 335-336.

A.K. Sharma and S.K. Sarkar (1956). Cytological basis of differentiation in Palms. Sci.

Cult. 22 : 175-176.

A.K. Sharma and A. Majumder (1956). Karyotypic variation in Pteriodophyta and their significance. Agron. Lusit. 18 : 243-249.

A.K. Sharma and N.K. Bhattacharyya (1956). An investigation on the karyotype of the genus Crinum and its phylogeny. Genetica 28 : 263-296.

A.K. Sharma and A.K. Bal (1956). A cytological study of a few genera of Amaryllidaceae with a view to find out the basis of their phylogeny. Cytologia 21 : 329-352.

A.K. Sharma and C. Ghosh (1956). The cytology of two varieties of Polyanthes tuberose with special reference to their interrelations and sterility. Genetica 28 : 99-111.
A.K. Sharma and B. Bhattacharyya (1956). A study of the cytology of four members of the Hydrocharitaceae as an aid to trace the lines of evolution. Øyton 6 : 123-134.

A.K. Sharma and D.N. De (1956). Polyploidy in Dioscorea. Genetica 28 : 112-120.

A.K. Sharma and A.K. Bal (1956). A cytological investigation of some members of the family Cyperaceae. Øyton 6 : 7-22.

A.K. Sharma and D.N. De (1956). Cytology of some of the millets. Caryologia $8: 294-308$.

A.K. Sharma and N.K. Bhattacharyya (1956). A study on spontaneous chromosome fragmentation in Vicia sativa Linn. Cytologia 21 : 361-375.

A.K. Sharma and N.K. Bhattacharyya (1956). Cytogenetics of some members of Portulacaceae and related families. Caryologia 8 : 257-274.

A.K. Sharma (1956). Chromosome studies in some Indian Barley I. Proc. Nat. Inst. Sci. Ind. 22 : 246-254.

A.K. Sharma and R.N. Mukherji (1956). Chromosome studies in some Indian Barley II. Proc. Ind. Acad. Sci. 43 : 279-287.

A.K. Sharma and B.Bhattacharyya (1956). Vitamins - their property of inducing chromosome division in adult cell of plants. Caryologia 9 : 38-53.

A.K. Sharma and A. Dutta (1956). Induction of chromosome division by ascorbic acid treatment. Øyton 6 : 71-78.

A.K. Sharma and R.K. Mukherji (1956). Effect of irradiation on adult nuclei in plants. Genetica 28 : 143-164.

A.K. Sharma and B. Bhattacharyya (1956). Effect of inositol and molybdic acid on somatic nuclei of plants. Øyton 7 : 15-22.

A.K. Sharma and M. Roy (1956). Chemical constitution and enzyme activity of chromosomes and related structures. $\mathrm{La}$ Cellule 58 : 109-133.

A.K. Sharma and M. Roy (1956). The acid phosphatase test in the analysis of chromosome structure. Øyton $7: 23-36$.

A.K. Sharma and M. Roy (1956). Irradiation - its effect on young metabolic nuclei and phosphatase activity in plants. La Cellule 57 : 337-354.

A.K. Sharma and S.K. Sarkar (1956). Cytology of different species of palms and its bearing on the solution of the problems of phylogeny and speciation. Genetica 28 : 361-488.

A.K. Sharma and S.K. Sarkar (1956). Cytology of two species of Onagraceae with special reference to the structural hybridity of Clarkia. Øyton 7 : 69-76.

A.K. Sharma and A. Sharma (née Mookerjea) (1957). Vegetatively reproducing plants - their means of speciation. Sci. Cult. 22 : 628-630.

A.K. Sharma and B. Bhattacharyya (1957). Effects of chemical treatments on floral shoots. Ind. Agriculturist $1: 27-33$.

A.K. Sharma and B. Bhattacharyya (1957). Cytology of six species of Asparagus and Lilium. Øyton 8 : 1-12.

A.K. Sharma and B. Bhattacharyya (1957). An investigation on the biochemical basis of tumour-like growth in root tips induced by chemicals. Bull. Bot. Soc. Beng. 11 : 34-40. 
A.K. Sharma and N.K. Bhattacharyya (1957). Cytology of Asphodelus tenuifolius Cav. Caryologia 10 : 330-339.

A.K. Sharma and A.K. Bal (1957). Chromosome studies in Citrus I. Agron. Lusit. 19 : 101-126.

A.K. Sharma and D. Bhattacharjee (1957). Chromosome studies in Sorghum I. Cytologia 22 : 287-311.

A.K. Sharma and U.C. Bhattacharyya (1957). Cytological studies in Begonia I. La Cellule 58 : 307-329.

A.K. Sharma and S.K. Sarkar (1957). A study of the comparative effect of chemicals on chromosomes of roots pollen mother cells and pollen grains. Proc. Ind. Acad. Sci. 45 : 288-293.

A.K. Sharma and A. Sharma (1957). A theory regarding the stability of chromosome complement in a species. Naturwiss. 44 : $1-17$.

A.K. Sharma and A. Sharma (1957). Evidences of cytological basis of differentiation in plants. Experientia 13 : 143-145.

A.K. Sharma and A. Sharma (née Mookerjea) (1957). Investigations leading to a theory of differentiation in plant cells. Genet. Iber. 9 : 143-162.

A.K. Sharma and A. Sharma (1957). Permanent smears of leaftips for the study of chromosomes. Stain Techn. 32 : 167-169.

A.K. Sharma and A. Sharma (1957). Karyotype studies in Cestrum as an aid to taxonomy. Genetica $29: 83-100$.

A.K. Sharma and C. Talukdar (1957). Structural heterozygosity of Cipura paludosa Aubl. Nature 180 : 662-663.

A.K. Sharma and A.K. Chatterji (1957). A cytological investigation of some Convolvulaceae as an aid in understanding their lines of evolution. Øyton 9 : 143-157.

A.K. Sharma and B. Bhattacharyya (1957). An investigation on the biochemical basis of tumour-like growth in root tips induced by chemicals. Bull. Bot. Soc. Bengal 11 : 34-40.

A.K. Sharma and A. Sharma (1958). Further investigations on cytology of members of the family Commelinaceae with special reference to the role of polyploidy and the origin of ecotypes. F. Genet. 56 : 1-22.

A.K. Sharma and M. Jash (1958). Further investigation on the cytology of the Amaryllidaceae. Øyton 11 : 103-110.

A.K. Sharma and N.K. Bhattacharyya (1958). Inconstancy in chromosome complements in species of Maranta and Calathea. Proc. Nat. Inst. Sci. Ind. 24 : 101-117.

A.K. Sharma and N.K. Bhattacharyya (1958). Structure and behavior of chromosomes of species of Acacia. Øyton 10 : 111-122.

A.K. Sharma and A. Sharma (1958). Analysis of chromosome morphology and possible means of speciation in Jasminum. Cytologia 23 : 172-185.

A.K. Sharma and M. Roy (1958). Cytological studies on Jute and its allies I. Agron. Lusit. $20: 5-15$.

A.K. Sharma and A. Sharma (1958). Recent advances in the study of chromosome structure. Botanical Review 24 : 511 5491958.
A.K. Sharma and A.K. Chatterji (1958). Chromosome studies as a means of detecting the method of speciation in some members of Liliaceae. Genet. Iber. 10 : 149-178.

A.K. Sharma and A.K. Bal (1958). A cytological study on the different varieties of Codiaeum variegatum $\mathrm{Bl}$. As a means of finding out the mechanism of their evolution. Nucleus 1 :223-226.

A.K. Sharma and A. Sharma (née Mookerjea) (1959). Chromosomal alterations in relation to speciation. Botanical Review 25 : 514-544.

A.K. Sharma and N.K. Bhattacharyya (1959). Cytology of several members of Zingiberaceae and a study of the inconstancy of their chromosome complements. La Cellule 59 : 299-346.

A.K. Sharma and N.K. Bhattacharyya (1959). Cytological studies on different species of Mentha with special reference to the occurrence of chromosomal biotypes. Cytologia 24 : 198-212.

A.K. Sharma and N.K. Bhattacharyya (1959). Experimental study to compare the effect of X-ray on the somatic chromosomes of a few species of Monocotyledons. Cytologia 24 : 241-252.

A.K. Sharma and N.K. Bhattacharyya (1959). Chromosome studies on two genera of the family Piperaceae. Genetica 29 :256-289.

A.K. Sharma and N.K. Bhattacharyya (1959). Chromosome studies on four different species of Cinnamomum. Jap. J. Bot. $17: 43-54$.

A.K. Sharma and N.K. Bhattacharyya (1959). Further investigations of several genera of Umbelliferae and their interrelationships. Genetica 30 : 1-62.

A.K. Sharma and B. Varma (1959). The somatic chromosomes of 5 species of Artistolochia. Øyton 12 : 101-108.

A.K. Sharma and B. Varma (1959). Study of the effects of chemicals on endosperm chromosomes of Cestrum diurnum Linn. Cytologia 24 : 498-506.

A.K. Sharma and M. Chaudhuri (1959). As aspect of gammexane (hexachlorocyclohexane) effect on chromosomes. Curr. Sci. 28 : 498-499.

A.K. Sharma and A.K. Bal (1959). Comparative effect of the bark extract of the members of Apocynaceae on plant tissue. Port. Acta Biol. 6 : 45-64.

A.K. Sharma and A. Gupta (née Majumdar) (1959). Chromosome breakage with plant pigments. Nature 184 : 1821.

A.K. Sharma and A.K. Bal (1959). Further investigation into the cytology on the varieties of Polyanthes tuberose with special emphasis on the occurrence of biotypes. Jour. Univ. Gauhati 10 : 65-76.

S. Mukhopadhyay and A.K. Sharma (1959). A new technique for karyotype study of Oryza. Rice News Letter (October).

A.K. Sharma and C. Talukdar (1959). Cytotaxonomical studies on some members of the Iridaceae with special reference to the structural heterozygosity of Cipura paludosa Aubl. Nucleus 2 : 63-84. 
A.K. Sharma and A.Gupta (1959). Induction of chromosome breakage through plant pigments. Nucleus 2 : 131-160.

A.K. Sharma and A. Dutta (1959). Effect of riboflavin on plant nuclei. Genet. Iber. 11 : 129-144.

A.K. Sharma and L.K. Jhuri (1959). Chromosome analysis of some grasses I. Genet. Iber. 11 : 145-174.

A.K. Sharma and P.C. Datta (1960). Chromosome studies in species of Dracaena with special reference to their means of speciation. J. Genet. $57:$ 43-76.

A.K. Sharma and N.K. Bhattacharyya (1960). An investigation on the scope of a number of pretreatment chemicals for chromosome studies in different groups of plants. Jap. J. Bot. 17 : 152-162.

A.K. Sharma and A.K. Chatterjee (1960). Effect of asparagines on plant nuclei. Caryologia 12 : 404-413.

A.K. Sharma and T. Chatterjee (1960). Chromosome studies of some members of Polygonaceae. Caryologia 13 : 486-506.

A.K. Sharma and T. Chatterjee (1960). Ranunculus scleratus Linn. - its cytology and response to gammexane treatment. Ind. Agriculturist. 4 : 81-89.

A.K. Sharma and U.C. Bhattacharyya (1960). Cytological investigations on Bougainvillea as an aid in interpreting the evolution and affinities of different species and varieties. Nucleus 3 : 19-75.

A.K. Sharma and T. Chatterjee (1960). Cytological studies on three species of Oxalis. Caryologia 13 : 755-765.

A.K. Sharma and A. Sharma (1960). Spontaneous and chemically induced chromosome breaks. International Review of Cytology 10 : 101-136.

A.K. Sharma and A. Sharma (1960). Amino-acid interference in chromosome metabolism. Nucleus 3 : 215-224.

A.K. Sharma and C. Talukdar (1960). Chromosome studies in members of the Iridaceae and their mechanism of speciation. Genetica 31 : 340-384.

A.K. Sharma and T. Chatterjee (1960). Chromosome studies in Ixora. Genetica 21 : 421-447.

A.K. Sharma (1960). Plant Cytogenetics. Ann. Rev. Biochemical \& Allied Res. in India 31 : 79-159.

A.K. Sharma (1960). Recent advances in the study of chromosome structure. Proc. Summer School of Botany 445-451.

A.K. Sharma and L.K. Jhuri (1960). Pollen abnormality and meiotic irregularity in Seprina pendula Schnizl. Bull. Bot. Soc. Beng. $11: 67-70$.

A.K. Sharma and U.C. Bhattacharyya (1960). Colchicine effect on pollen mother cells and pollen grains of Zebrina pendula Schnizi. Jap. J. Bot. 17 : 438-445.

A.K. Sharma and T. Chatterjee (1961). Structural hybridity in a diploid Taraxacum. Naturwiss. 4 : S109-110.

A.K. Sharma and A.K. Chatterji (1961). The chromosome numbers of a few more orchid genera. Curr. Sci. $30: 75$.

A.K. Sharma and C.Talukdar (1961). Effect of X-rays on meiotic chromosomes of Cipura paludosa Aubl. III. Proc. Nat. Sci. India 27B : 6-12.
A.K. Sharma and A. Sharma (1961). Chromosome studies of some varieties of Narcissus tazetta L. Carylogia 14 : 97-106.

A.K. Sharma and A. Sharma (1961). An investigation of the cytology of some species of Liliaceae. Genet. Iber. 13 : 25-42.

A.K. Sharma and A. Sharma (1961). A comparative study of the effect of RNA and DNA treatment on somatic nuclei in plant cells. Histochemie 2 : 260-265.

A.K. Sharma and H.R. Aiyangar (1961). Occurrence of B-chromosomes in diploid Allium stracheyi Baker and their elimination in polyploids. Chromosoma 12 : 310-317.

A.K. Sharma and T.P. Chatterjee (1961). Phosphatase activity in plant cells with special reference to those treated with colchicines and gammexane. Cytologia 26 : 12-19.

A.K. Sharma and U.C. Bhattacharyya (1961). X-ray action on pollen mother cells pollen grains and root cells of Rhoeo discolor Hance. Proc. Nat. Inst. Sci. Ind. 27B :116-125.

A.K. Sharma and U.C. Bhattacharyya (1961). Further investigation on the cytology of some members of Nyctaginaceae. Ind. Agriculturist. 5 : 9-28.

A.K. Sharma and M. Chaudhuri (1961). A detailed analysis of the control of temperature on gammexane-induced polyploidy and different cell injuries. Nucelus 4 :157-168.

A.K. Sharma and K.B. Datta (1961). Interstrain differences in karyotypes of Raphanus sativus Linn. Ind. Agriculturist. 6 : 151-159.

A.K. Sharma and A. Sharma (1961). Cytology of some members of the family Iridaceae. Cytologia 26 : 274-284.

A.K. Sharma and K.B. Datta (1961). A cytological study to work out the trend of evolution in Aglaonema Richardia. Caryologia 14 : 439-454.

A.K. Sharma and U.C. Bhattacharyya (1961). Structure and behavior of chromosomes in species of Anthurium with special reference to the accessory chromosomes. Proc. Nat. Inst. Sci. Ind. 27B : 317-328.

A.K. Sharma and A. Sharma (1961). Application of diastase in cytological techniques. Acta. Histochem. 12 : 241-246.

A.K. Sharma and T.P. Chatterjee (1961). Nuclear response to haemoglobin treatment. Annali di Botanica 27 : 1-7.

A.K. Sharma and U.C. Bhattacharyya (1962). A cytological study of the factors influencing evolution in Agave. La Cellule $62: 259-279$.

A.K. Sharma and A. Sharma (1962). Polyploidy and chromosome evolution in Hibiscus. La Cellule 62 : 283-300.

A.K. Sharma and A.K. Chatterjee (1962). Chromosome size as a factor in radiosensitivity. Nucleus 5 : 67-74.

A.K. Sharma and M. Chaudhuri (1962). An investigation on the viscosity changes in the cell caused by coumarin and its derivatives. Nucleus 5 : 137-142.

A.K. Sharma and A.K. Chatterji (1962). An investigation of the genomic influence on radiosensitivity. Proc. Nat. Inst. Sci. Ind. 28B : 478-484. 
A.K. Sharma and A. Sharma (1962). A study of the importance of nucleic acids in controlling chromosome breaks induced by different compounds. Nucleus 5 : 127-136.

A.K. Sharma and U.C. Bhattacharyya (1962). The differential effect of colchicines on seeds and seedlings of Trigonella foenum-graecum L. and the influence of temperature on the effect. Øyton $18: 39-50$.

A.K. Sharma and K.B. Datta (1962). Radiomimetic effects of plant pigments. Folia Biologica 10 : 59-65.

M. Chaudhuri D.P. Chakraborty and A.K. Sharma (1962). Isopsoralene and its use in karyotype analysis. Stain Techn. 37 : 95-97.

A.K. Sharma and U.C. Bhattacharyya (1962). Cytological studies in Begonia II. Caryologia 14 : 279-301.

A.K. Sharma and A.K. Chatterji (1962). Cytology of the genera of Caryophyllaceae with special reference to the mechanism of speciation in Gypsophila. Ind. Agriculturist 1 :21-30.

A.K. Shrma and K.B. Datta (1962). An investigation on the cytotypes of Haworthia. Genet. Iber. 14 : 131-155.

A.K. Sharma and S. Mukhopadhyay (1963). Chromosome study in Agapanthus and the phylogeny of its species. Caryologia 16 : 127-137.

A.K. Sharma M. Chaudhuri and D.P. Chakraborti (1963). Chemical basis of the action of natural coumarin and its derivatives on chromosome breakage. Acta. Biologica et Medica Germanica 11 : 433-441.

A.K. Sharma and T. Chatterji (1963). Radiation study as a means of working out the strain difference of Pisum sativum L. Folia Biologica 11 : 158-168.

A.K. Sharma and A.K. Sarkar (1963). Influence of temperature on the manifestation of colchicines action. Rev. Port. Zool. Biol. Geral. 4 : 29-36.

A.K. Sharma and R.K. Chaudhuri (1963). Differential susceptibility of Lathyrus chromosomes to p-dichlorobenzene and coumarin treatment. Rev. Port. Biol. Zool. Geral.4 : 21-27.

A.K. Sharma and S. Mukhopadhyay (1963). Cytotaxonomic investigation with the aid of an improved method on the family Verbenaceae with special reference to the lines of evolution. J. Genet. 58 : 358-386.

A.K. Sharma and A.K. Sarkar (1963). Differential effects of chemicals on euchromatin and heterochromatin. Nucleus 6 : 135-140.

A.K. Sharma and R.K. Chaudhuri (1963). Factors controlling the effect of chlorophyll on chromosomes. Annali di Botanica 27 : 555-564.

A.K. Sharma and A.K. Sarkar (1963). Cytological analysis of different cytotypes of Colocasia antiquotum. Bull. Bot. Soc. Bengal 17 : 16-22.

A.K. Sharma and A.K. Sarkar (1964). Investigations on chemical protection against radiation damages. Øyton $21: 47-53$.

A.K. Sharma and S. Mukhopadhyay (1964). Karyotype constancy in different strains of Lens esculenta Moench as worked out through recent techniques. Ind. Agriculturist 7 : 103-111.

A.K. Sharma and C. Talukdar (1964). The effect of moisture on radiosensitivity in root-tips of Vicia sativa Linn. Nucleus 7 : 23-28.

A.K. Sharma and M. Chaudhuri (1964). Cytological studies as an aid in assessing the status of Sansevieria Ophiopocon and Curculico. Nucleus 7 : 43-58.

A.K. Sharma and A.K. Chatterjee (1964). Cytological study as an aid in the interpretation of the systematic status of the different genera of Araliaceae. Cytologia 29 : 1-12.

A.K. Sharma and A.K. Sarkar (1964). Studies on the cytology of Caladium bicolor with special reference to the mode of speciation. Genet. Iber. $16: 21-47$.

A.K. Sharma and A.K. Sarkar (1964). A study on the structure and behavior of chromosomes in different species of Yucca. Bot. Tiddskrift. 60 : 180-190.

A.K. Sharma and A.K. Chatterjee (1964). Amino-acid constitution of chromosomes. J. Histochem. Cytochem. 12 : 266-270.

A.K. Sharma and T. Chatterjee (1964). Effect of oxygen on chromosomal aberrations induced by hydroquinone. Nucleus 7 : 113-124.

A.K. Sharma (1964). Cytology as an aid in taxonomy. Bull. Bot. Soc. Bengal $18: 1-4$.

A.K. Sharma and Chitra Talukdar (1965). Effect of gammexane on pollen mother cells of Allium cepa. Biologia 20 : 105-108.

A.K. Sharma and S. Mukhopadhyay (1965). Cytological study on two genera of Araceae and correct assessment of their taxonomic status. Genetica Agraria 18 : 603-616.

A.K. Sharma and M. Banik (1965). Cytological investigation of different genera of Amaranthaceae with view to trace their interrelationships. Bull. Bot. Soc. Bengal 19 :40-50.

A.K. Sharma and S. Mukhopadhyay (1965). Chromosome studies in Typhonium and Arisaema with a view to find out the mode of origin and affinity of the two. Cytologia 30 : 58-66.

A.K. Sharma and A.K. Sarkar (1965). Chromosome study in different genera of Combretaceae. J. Ind. Agriculturist 9 : 100-106.

A.K. Sharma and S. Mukhopadhyay (1965). Application of improved method on karyotype analysis of different species and varieties of Oryza. Oryza 3 : 23-37.

A.K. Sharma and A.K. Chatterji (1966). Cytological studies on orchids with respect to their evolution and affinities. Nucleus 9 : 177-203.

G.N. Bhattacharyya and A.K. Sharma (1966). A cytotaxonomic study on some taxa of Araceae. Genet Iberica $18: 237$.

A.K. Sharma and G.N. Bhattacharyya (1967). A study on the effects of antibiotic treatment on chromosomes. Acta. Biologica (Hungary) $18: 67$.

A.K. Sharma and D. Tulsi Raju (1967). Cytological analysis of six species of Chlorophytum. Bull. Bot. Soc. Bengal 21 : 37-46. 
D. De and A.K. Sharma (1967). Chromosome studies in the genus Centaurea. Folia Biologica 15.

A.K. Sharma and D. De (1967). A comprehensive cytotaxonomic study on the family Chenopodiaceae. J. Cyto. Genet. 2.

A.K. Shrma and T. Chatterjee (1967). Cytotaxonomy of helobiae with special reference to the mode of evolution. Cytologia 32 : 286-307.

A.K. Sharma and A.K. Sarkar (1967). An investigation of the factors responsible for chromosome breakage by plant pigments. Genetica Agavira 21 : 77-85.

G. Talukder and A.K. Sharma (1967). Cytochemical studies on human malignant neoplasm. Nucleus 10 : 208-215.

A.K. Sharma (1967). Evolution and taxonomy of monocotyledons. Chromosomes Today II. Oliver and Boyd London.

G. Talukder (née Mukherjea) and A.K. Sharma (1968). Assessment of the technique for differential localization of DNA and RNA. Nucleus 11 : 106-110.

G. Mookerjea and A.K. Sharma (1968). Cytochemical study of induced malignant tumours in rat. Ind. J. Exp. Biol. 6 : 67-69.

T. Chatterjee and A.K. Sharma (1968). Cytological studies of different genera of three tribes of Compsitae. Bull. Bot. Soc. Bengal 22 : 101-104.

A.K. Sharma (1968). Facets and problems of chromosome analysis. Sci. Cult. 34 (Suppl.) : 69-71.

G. Talukder and A.K. Sharma (1968). Assessment of factors controlling technique for differential localization of RNA and DNA. Nucleus 11 : 106-110.

A.K. Sharma and I. Ghosh (1968). Cytotaxonomy of Dracaena. J. Biol. Sci. $11: 45-55$.

A.K. Sharma and D.T. Raju (1968). Structure and behavior of Chromosomes in Bauhinia and Allied Genera. Cytologia 33 : 411-426.

A.K. Sharma (1969). Material basis of heredity. Bull. R.K.M. Inst. of Culture 20 : 167-171.

G. Talukder and A.K. Sharma (1969). Cytological study of induced tumours in rat. Ind.J. Cancer 6 : 93-98.

A.K. Sharma (1969). Problems of the structure and behavior of chromosomes. La Kromosomo 75 : 2449-50.

A.K. Sharma (1969). Evolution of structure and function of chromosome. Nucleus 12 : 86-92.

D. Tulsi Raju and A.K. Sharma (1969). Cytological studies on some members of Amaryllidaceae. Bull. Bot. Soc. Bengal J. Sen Memorial Vol. 399-410.

T. Chatterjee and A.K. Sharma (1969). Cytotaxonomy of Cichoriear. Genetic 40: 577-590.

I. Ghosh and A.K. Sharma (1969). Chromosome studies in Dioscorea. Plant Science $1: 1-9$.

T.P. Chatterjee and A.K. Sharma (1969). Amino acid metabolism and spindle effect. Ind.J. Hered. 1 : 107-123.
T. Chatterjee and A.K. Sharma (1970). Chromosome breakage through water treatment. Rev. Romaine Embryol. Cytol. 7 : $1-10$.

D. Tulsi Raju and A.K. Sharma (1970). Chromosome analysis in the genus Manfreda. J. Gauhati Univ. XVIII-XIX. Science.

G.N. Bhattacharyya and A.K. Sharma (1970). Cytological study of some members of Compositae. Bull. Botan. Soc. Bengal 24 :31-36.

T.P. Chatterjee and A.K. Sharma (1971). An analysis of the effects of cell separating agents. Biologia 26 : 309-316.

A.K. Sharma and I. Ghosh (1971). Cytotaxonomy of the family Bromoliaceae. Cytologia 36 : 237-247.

M. Banerjee and A.K. Sharma (1971). Effects of certain physical and chemical agents on the chromosome of different varieties of Allium cepa. Ind. Agric. 15 : 199-206.

G.Talukder and A.K. Sharma (1971). Chromosome analysis of some malignant human neoplasms. Acta evol. Acad. Sci. Hung. 22 : 19-23.

A.K. Sharma (1971). Focus on pollution - editorial. Sci. Cult. $37: 61-65$.

P.K. Banerjee and A.K. Sharma (1971). Comparative thin-layer chromatography of normal and cholchiploid ipecac. J. Indian Bot. Soc. Golden Jub. Vol 50A : 302-307.

M. Banerjee and A.K. Sharma (1971). A cytotaxonomical analysis of several genera of the family Iridaceae. Plant Science $\mathbf{8}$ : 14-29.

A.K. Sharma (1972). Genes Virus and Cancer. Everyman's Science 7 : 107-110.

A.K. Sharma (1972). Dynamicity of chromosomes - understanding and application. Jour.Sci. Ind. Res. 31 : 545-546.

A.K. Sharma (1972). Progress of Botany. In "A decade (1963-72) of Science in India”Indian Science Congress Association Diamond Jubilee Vol. 1972 pp. 1-246.

A.K. Sharma (1973). Share of Biological Sciences in R \& D allocation. Sci. Cult. $39: 285$.

A.K.Sharma (1974). Plant Cytogenetics. The Cell Nucleus 2 : 264-292 ed. H. Busch Academic Press New York.

A.K. Sharma (1975). Genetics and Society editorial. Sci. Cult. $41: 1-3$.

A.K.Sharma(1975).The concept of chromosome dynamism control of differentiation reproduction and metabolism in eukaryote. Nucleus 18 : 93-97.

A.K. Sharma (1975). Chromosome banding and repeated DNA. Birbal Sahni Gold Medal Lecture. J. Ind. Bot. Soc. 54 : 1-8.

D. Bhattacharyya and A.K. Sharma (1975). X-ray effects on a few varieties of Caladium bicolor Vent. (Araceae). J. Cytol. Genet. Congr. Suppl. 25-28.

P.Ghosh and A. K. Sharma (1975). Emryo culture as a tool of securing viable mutants after EMS treatment. J. Cytol. Genet. Congr. Suppl. 87-90. 
A. Pal and A.K. Sharma (1976). Accessory chromosome and chromosome variability in Smilax zeylanica L. Nucleus 19 : 63-67.

A.K. Sharma (1976). A new look at chromosome and its Evolution. Proc. Indian Nat. Sci. Acad. 42 : 12-24.

A. Pal and A.K. Sharma (1976). Radiation treatment and diosgenin content in Dioscorea bulbifera L. Proc. Ind. Natl. Sci. Acad. 42B : 156-161.

K. Sikka and A.K. Sharma (1976). The effects of some herbicides on plant chromosomes. Proc. Indian Natl. Sci. Acad. 42B : 299-307.

A.K. Sharma (1976). Additional Genetic elements in chromosomes. The Nucleus 21 :113-116.

A.K. Sharma (1977). Evidence of dynamism as a basis of chromosomal control of genetic reactions. Nucleus 20 : 4-10.

A. Pal and A.K. Sharma (1977). Diasgenin content of old and new world species of Dioscoria with special reference to the chromosomal races. Ind. J. Exp. Biol. 15 : 1109-1112.

A.K. Sharma (1977). Cytogenetics and Agriculture. Basic Sciences on Agriculture. Ind. Nat. Sci. Acad. Bull. 55 : 16-24.

A.K. Sharma (1978). Change in chromosome concept. Proc. Ind. Acad. Sci. 87B :161-190.

A.K. Sharma and A Hore (1978). Chromosome evolution in Umbelliferae. Phyta 1 :109-116 (Acc. 1975).

M. Banerjee and A.K. Sharma (1979). Variations in DNA content. Experientia 35 :42-43.

P. Ghosh G.C. Mitra and A.K. Sharma (1979). Embryo culture as a tool for securing viable mutants in certain legumes after gamma-ray treatment. Ind. J. Heredity 2: 1-15.

A. Pal and A.K. Sharma (1979). Certain chemical components of Dioscorea alata L. as affected by X-irradiation. Ind. J. Exp. Biol. 17 : 144-147.

K. Sikka and A.K. Sharma (1979). Chromosome evolution in certain genera of Brassiceae. Cytologia 44 : 467-477.

P. Ghosh G.C. Mitra and A.K. Sharma (1979). Effect of gammairradiation on callus growth of Vigna sinensis (L) Savi. Curr. Sci. 48 : 731-732.

U.C. Lavania and A.K. Sharma (1979). Giemsa C-banding polymorphism in Lathyrus odoratus L. Nucleus 22 : 34-37.

U.C. Lavania and A.K. Sharma (1979). Trypsin - orcein banding in plant chromosomes. Stain Techn. 54 : 261-263.

P. Ghosh G.C. Mitra and A.K. Sharma (1979). Embryo culture as amethod of securing viable mutants in Vigna sinensis var. black and V. radiate (B-105) after EMS treatment. Proc. Indian Natl. Sci. Acad. B45 : 605-612.

P. Ghosh and A.K. Sharma (1979). Chromosome analysis in suspension culture in Vigna sinensis var. black and Pisum sativum L. Caryologia 32 : 419-424.

A. Bhattacharjee and A.K. Sharma (1980). Karyological investigation on three genera of Ranunculaceae. Acta Botanica Indica $8: 1-10$.
U.G. Lavania and A.K. Sharma (1980). Giemsa C-banding in Lathyrus L. Bot. Gaz. 14 : 199-204.

A.K. Sharma (1980). Genes and Chromosomes. In Science Review 1 : 1-28. Indian Science News Association Calcutta.

A. Pal and A.K. Sharma (1980). Analysis of cytotypes of Dioscorea and scope of increasing the diosgenin content. $\mathrm{La}$ Cellule 73 : 117-134.

U.C. Lavania and A.K. Sharma (1980). Giemsa C-banding somatic association and orientation of interphase chromosomes in Trigonella foenum-graecum (L.). Caryologia 33 : 17-23.

H. Sau A.K. Sharma and R.K. Chaudhuri (1980). DNA RNA and protein content of isolated nuclei from different plant organs. Indian J. Exptl. Biol. 18(12) : 1519-1523.

Mantu De and A.K. Sharma (1980). Cardenolide contents in difference genotypes of Thevetia nerifolia and Nerium odorum. The Nucleus 23(3) : 213.

A.K. Sharma and S.N. Sahay (1980). Use of polygraphs as an aid in tracing affinities in Polygonaceae. Golden Jubilee Commemoration Volume. Natl. Acad. Sci. India 541-550.

A.K. Sharma (1980). An introduction to genes and chromosomes. Science Review Indian Science New Association 1 : $1-28$.

N. Banerjee and A.K. Sharma (1981). In vitro culture of leaf cell of Rauwolfia serpentine Benth for the induction of callus and roots with reference to cytodifferentiation. Cell and Chr. Newsletter 4(1) : 17-19.

T.P. Singh and A.K. Sharma (1981). Chromosome analysis as correlated with the chemical constituents and status of two species of Ocimum. Agron. Lurit. 40(3) : 287-298.

T.P. Singh and A.K. Sharma (1981). Cytotypes and phenotypes in Ocimum sanctum - their characteristics. Cytologia 46 : 723-729.

A.K. Sharma (1981). Evolution of cell and chromosome in Eukaryota. J. Indian Bot. Soc. 60 : 1-8.

A.K. Sharma (1981). DNA repeats and their terminology. The Nucleus 24 : 87-92.

U.C. Lavania and A.K. Sharma (1981). An interphase model for mitotic chromosome orgnaisation in Eukaryota. Biosystems $14: 171-179$.

A.K. Sharma and T.P. Singh (1981). Correlation of cytology and phytochemical constituents in Labiatae. Bol. Soc. Broteriana Ser. 2 53(2) : Fernaudes Comm. Volume :1257-86.

U.C. Lavania and A.K. Sharma (1982). Heterochromatin in perspective. Curr. Sci. 51 : 175-180.

A.K. Sharma (1982). Organisation of chromosome with special reference to the human system. Cell and Chromosome Newsletter 5(1) : 1-6.

M. De M. Banerjee and A.K. Sharma (1982). Quantitative estimation of Diosgenin in different populations of Costus speciosus. Curr. Sci. 51(2) : 993-994. 
T.P. Singh and A.K. Sharma.Chromosome analysis as correlated with chemical constitution and status of two species of Ocimum.

A.K. Sharma (1982). Genetic approaches in modern biology. In: M.G.K. Menon and A. Sharma (eds.), Basic research as an integral component in Science and Technology. Focal theme ISCA publ. pp. 74-81.

U.C. Lavania and A.K. Sharma (1983). Chromosome banding in evolutionary plant cytogenetics. Proc. Ind. Sci. Acad. 92(B) : 51-79.

M. De and A.K. Sharma (1983). Cytomix adc and pollen mother cells of ornamental Ervatamia divaricata Linn. Cytologia $\mathbf{4 8}$ : 201-207.

A.K. Sharma (1983). Additional genetic materials in chromosomes. Kew Chromosome Conference II Allen \& Unwin pp. 35-42.

U.C. Lavania and A.K. Sharma (1983). On interchromosomal connections in plants. Experientia.

S. Chattopadhyay and A.K. Sharma (1983). Genetic diversity in Costus speciosus (Koen). Cytologia 48 : 209-214.

H. Sau and A.K. Sharma (1983). Chromosome evolution and affinity of certain genera of Orchidaceae. Cytologia 48 : 363-372.

J. Jose and A.K. Sharma (1983). Chromosome composition in relation to chemical constitution in varieties of Piper Linn. Nucleus 26(2) : 78-86.

A.K. Sharma (1984). Chromosome structure as revealed through recent techniques. In Perspectives in Cytology and Genetics. Eds. G.K. Manna and U. Sinha. 4 : 9-13.

S. Mukhopadhyay and A.K. Sharma (1984). Study of DNA content in different species of Calathea at the interspecific level. In : Perspectives in Cytology and Ggenetics 4 :43-46.

A.K. Sharma (1985). Additional DNA sequences - topography property role and evolutionary significance. Proc. Indian Acad. Sci. (Plant Science) 94(1) : 1-18.

J. Jose and A.K. Sharma (1985). Structure and behavior of chromosomes in Piper and Peperomia (Family Piperaceae). Cytologia (Tokyo) 50.

A.K. Sharma (1985). Genetic futures. Science Age 12-17.

A.K. Sharma (1985). Chromosome structure. Perspective Report Ser 14 Golden Jubilee Publications. Indian National Science Academy 1-22.

U.C. Lavania and A.K. Sharma (1985). Arrangement of the interphase chromosomes in the nucleus. The Journal of Heredity 76 : 395-396.

J.Sengupta G.C. Mitra and A.K. Sharma (1985). Comparative effect of two different auxins on growth and cytology of Dioscorea floribunda callus culture. Bang. J. Bot. 14(1) : 62-67.

S. Mukherjee and A.K. Sharma (1985). Estimation of in situ DNA content in organs of different strains of Pisum sativum. The Nucleus 28(3) : 236-239.
N. Banerjee and A.K. Sharma (1985). Nuclear DNA and analysis of heterochromatin in different populations of Rauwolfia L. Proc. Ind. Natn. Sci. Acad. B51 : 505-510.

V.L.K. Rao and A.K. Sharma (1985). Protein patterns in species and varieties of Hordeum. The Nucleus 28(3) : 203-208.

N. Banerjee and A.K. Sharma (1985). Growth and chromosome analysis of callus of Rauwolfia serpentian Benth. Trends Pl. Res. 362-366.

A.K. Sengutpa G. Talukder and A.K. Sharma (1985). Serum proteins in cutaneous tuberculosis. Bionature 5(1) : 41-44.

T.P. Singh and A.K. Sharma (1986). Karyomorphological studies in Ocimum gratissimum L. and O. viride Willd. J. Cytol. Genet. $21: 15-20$.

J.S.P. Sarma and A.K. Sharma (1986). Karyomorphology of different strains of Maydeae. Cytologia 51 : 527-547.

A.K. Sharma (1986). Evolution of chromosome structure and eukaryotic cell. Pers. Cytol.Genet. 5 : 3-7.

J.S.P. Sarma and A.K. Sharma (1986). Nonrandom arrangement of satellite chromosomes in maize and its implications. Nucleus 29 : 39-44.

J. Sengupta G.C. Mitra and A.K. Sharma (1986). Cytomorphological studies of Dioscorea floribunda callus culture following gamma-irradiation. Nucleus 29 : 116.

A.K. Sharma (1986). Evolution of cell and chromosome structure in Eukaryota. Acta Biotheoretica (Netherlands) 35 : 69-75.

S. Mukherjee and A.K. Sharma (1986). Estimation of in situ DNA content in organs of different strains of Pisum sativum. Nucleus 28 : 236-239.

J. Sengupta G.C. Mitra and A.K. Sharma (1986). Chromosomal behavior in cultured cells of Dioscorea floribunda. Cytologia $51: 221-224$.

A.K. Kundu and A.K. Sharma (1986). Intraspecific variation in motherwort Leonurus sibiricus chromosome structure and amount of nucleic acid. Proc. Ind. Natn. Acad. $\mathbf{B 5 2}$ :485-489.

A.K. Sharma (1986). Chromosome Structure. Golden Jubilee Publ. INSA Series $16: 1-26$.

S. Mukherjee and A.K. Sharma (1986). In situ DNA quantitative in organs of different strains of Cicer arietinum L. Cytobios 48 : 151-156.

N. Banerjee and A.K. Sharma (1986). Genome studies at interand intraspecific levels of Rauwolfia. Phytobreedon 2 : 93-101 1986.

S. Mukhopadhyay and A.K. Sharma (1986). Induction maintenance and growth rate study of callus culture of Costus speciosus (Koen.). Sm. Pers. Cytol. Genet. 5 : 205-211 1986.

S. Mukhopadhyay and A.K. Sharma (1986). Chromosome studies in Calathea. Curr. Sci. 55 : 1146-1148 1986.

S. Mukherjee and A.K. Sharma (1986). Intervarietal relationships between chromosomesize nuclear DNA amount and 
protein content in Cajanus cajan (L) Millsp. Pers. Cytol. Genet. 5 : 735-740.

S. Mukherjee and A.K. Sharma (1987). Structure and behavior of chromosomes in the strains of Cicer arietinum L. Cytologia $52:$ 707-713.

S. Mukherjee and A.K. Sharma (1987). Cryptic structural differences at the interstrain level of Pisum sativum L. Cytologia $52: 793-800$.

V.L.K. Rao and A.K. Sharma (1987). Amount of DNA and genotypic differences in Hordeum. Cytologia 52 : 593-598.

J. Sengupta G.C. Mitra and A.K. Sharma (1987). Study of chromosomes in two callus lines and regenerated palnts of Kallstroemia pubescens. Cytologia 52 : 767-770.

A.K. Giri T.S. Banerjee G. Talukder and A.K. Sharma (1987). Induction of sister chromatid exchange and dominant lethal mutation by katha (catechu) in male mice. Cancer Letters 36 : 189-196.

A.K. Sharma (1988). Genetic toxicology : an introduction. Cell Biol. Toxicol. 4(4) :451-452.

N. Banerjee and A.K. Sharma (1988). In vitro response as a reflection of genomic diversity in long-term cultures of Musa. Theor. Appl. Genet. 76 : 733-736.

S. Banerjee and A.K. Sharma (1988). Polyploidy nuclear DNA and hecogenin in four species of Agave. Curr. Sci. 57 : 554-556.

D. Chattopadhyay and A.K. Sharma (1988). Sex differences and chromosomes in Putranjiva roxburghii Wall. Curr. Sci. 57 : 1017-1019.

A.K. Sharma and J.S.P. Sarma (1988). Chromosome structure rearrangements and genome relationship in Maydeae. Feddes Repertorium (Berlin) 99 : 291-337.

A.K. Kundu and A.K. Sharma (1988). A rapid screening technique for detection of Diosgenin through in situ cytophotometry. Stain Technol. 63 : 369-372.

N. Banerjee and A.K. Sharma (1988). Cytomixis in microsporocytes of Rauwolfia serpentine Benth. Curr. Sci. 57 : 267-268.

S. Banerjee and A.K. Sharma (1988). Structural differences of chromosomes in diploid Agave. Cytolotgia (Tokyo) 53 : 415-420.

A.K. Kundu and A.K. Sharma (1988). Cytomixis in Lamiaceae. Cytologia 53: 479-484.

D. Chattapadhyay and A.K. Sharma (1988). A new technique for orcein banding with acid treatment. Stain Techn. (USA) 63(5) : 283-289.

N. Banerjee S. Mukhoapdhyay and A.K. Sharma (1989). Cytogenetics of in vitro shoot bud proliferation of Solanum sarrachoides. Proc. Indin Acad. Sci. (Plant Sciences) 98(4) :1-6.

A. Sharma and A.K. Sharma (1989). Genetic toxicology testing of hazardous materials and wastes. In "Management of Hazardous Materials and Wastes-Treatment Minimization and
Environmental Impacts" (eds. S.K. Majumder E.W. Miller R.F. Schmalz). The Penn. Acad. Sci. (USA) 280-293.

J. Sengupta G.C. Mitra and A.K. Sharma (1989). Steroid formation during morphogenesis in callus culture of Dioscorea floribunda.. J. Plant Physiol. (Canada) 135 : 27-30.

J. Sengupta and A.K. Sharma (1989). Response to radiation and in vitro growth of two species of Luzula with non-localized centromere. Proc. Indian Acad. Sci. (Plant Sciences) 98 : 489-493.

A.K. Kundu and A.K. Sharma (1989). Diosgenin and DNa content in Costus specious (Koan). Indian Jour. Exp. Biol. 27 : 366-367.

S. Banerjee and A.K. Sharma (1989). Structure and behavior of chromosomes in four different species of Agave. Cytologia (Tokyo) $54: 39-44$.

N. Banerjee and A.K. Sharma (1989). Chromosome constitution and alkaloid content in Rauwolfia L. Apocynaceae. Cytologia (Tokyo) 54 : 19-24.

S. Banerjee and A.K. Sharma (1989). Quantitation of diosgenin in different cytotypes of Costus speciosus and its correlation with the amount of nuclear DNA. Cytobios (Cambridge) $\mathbf{5 8}$ : 141-147.

N. Banerjee S. Mukhopadhyay and A.K. Sharma (1989). Ontogenesis of in vitro shoot bud proliferation in Solanum sarrachoides Sendt. Proceedings of the Indian Academy of Sciences (Plant Sciences) 99(4) : 307-312.

A.K. Sharma (1990). Environmental hazards and nuclear changes. Environmental Monitering and Assessment (Netherlands) 14.

Jayanti Sen A.K. Sharma N.P. Sahu and S.B. Mahato (1993). Forskolin productionin untransformed root culture of Coleus forskohlii. Phytochemistry 34(5) : 1309-1312.

S. Mukherjee and A.K. Sharma (1993). In situ nuclear DNA content in perennial fast and slow growing acacias from arid zones. Cytobios 75 : 33-36.

K.K. Mandi and A.K. Sharma (1994). Chemical constitutents of Zingiberaceae as toaxonomic markers: A review. The Nucleus 37(3) : 123-131.

A.K. Sharma (1995). Plant Environment Interaction - Genetics of Stress Factors. Editor's Comments. The Nucleus 38(3) : 61-63.

D. Palit and A. K. Sharma (1995). Somatic chromosomal variations in speciation of Briza Festuca Cenchrus and Panicum (Gramineae). Cytobios 82 : 53-66.

S. Mukherjee and A.K. Sharma (1995). In situ nuclear DNA variation in Australian species of Acacia. Cytobios 83 : 59-64.

A. K. Sharma (1995). Antiquity of the plant kingdom and molecular world. Current Science 68(8) : 801-806.

A. K. Sharma (1996). Synchronization in mammalian system : An introduction. Methods in Cell Science 18 : 75-81 75-81. 
A.K. Sharma (1996). Editor's comments : Some thoughts on genetic factors and measures for plant improvement and sustainable growth. The Nucleus 39(1-2) : 1-3.

D. Palit and A.K. Sharma (1998). Somatic chromosomal variations in speciation of Briza Festuca Cenchrus and Panicum (Gramineae). Cytobios (Cambridge) $86: 72$.

P. Ghosh S. Mukherjee and A.K. Sharma (2000). Cytophotometric estimation of nuclear DNA content in several species of Araceae. Cytobios (Cambridge) $\mathbf{8 8}$.
A.K. Sharma (2000). Landmarks in Chromosome Research. M.N. Saha Lecture 1998. Indian National Science Academy Chennai. Nucleus 43 : 87-94.

P. Ghosh S. Mukherjee and A.K. Sharma (2001). Cytophotometric estimation of in situ DNA content in several species of Araceae. Cytobios (Cambridge) 105 : 177-183. 